\title{
ANALISIS WASTE DALAM ALIRAN MATERIAL INTERNAL DENGAN VALUE STREAM MAPPING PADA PT XYZ
}

\author{
Gita Ayu; Jeffry Hanggara; David Kurniawan; Gunawan \\ Department of Industrial Engineering, Faculty of Engineering, Binus University \\ Jln. K.H. Syahdan No. 9 Palmerah Jakarta Barat 11480 \\ KGAyu@binus.edu
}

\begin{abstract}
The main focus of the research is excess inventory and motion waste which commonly occur in warehouse and production floor. This research is carried out to minimize the average level and eliminate unnecessary motions, with consideration of electronic pull and traceability system characteristics. Product $X$, the highest-selling product, is the object of this research. To identify the current condition, the current state Value Stream Mapping (VSM) is developed as the basis to arrange improvement plan to minimize the wastes. Safety stock is determined through average and maximum consumption difference; and reorder point is determined to comply with pull approach. Average inventory level is calculated using continuous review method. The simulation was conducted and it was shown that 8.29 minutes is the maximum lateness. Thus, safety stock and reorder point are adjusted accordingly to anticipate stockout due to lateness. The improvement of process cycle efficiency is shown to increase from $4.1 \%$ to $5.1 \%$ as projected in future state VSM.
\end{abstract}

Keywords: waste, value stream mapping, pull, reorder point, continuous review, process cycle efficiency

\begin{abstract}
ABSTRAK
Hal yang menjadi perhatian utama dalam penelitian ini adalah adanya waste excess inventory dan motion dalam pengiriman material ke lantai produksi. Penelitian dilakukan untuk meminimalisasi waste tingkat persediaan dan mengeliminasi gerakan yang tidak perlu, sesuai dengan karakteristik sistem pull dan traceability elektronik yang akan diimplementasikan. Produk yang menjadi model line untuk perbaikan adalah brand $X$, yang merupakan produk dengan penjualan tertinggi. Untuk mengidentifikasi keadaan saat ini, dilakukan pemetaan current state Value Stream Mapping (VSM) sebagai landasan dalam menyusun rencana perbaikan untuk meminimasi pemborosan. Safety stock ditentukan menggunakan metode perbedaan maksimum dan ratarata, sedangkan untuk aplikasi pendekatan pull dilakukan penentuan reorder point. Average inventory level dihitung menggunakan metode continuous review. Berdasarkan simulasi, diperoleh hasil keterlambatan maksimum sebesar 8,29 menit. Maka, dilakukan penyesuaian safety stock dan reorder point untuk mengantisipasi stock-out akibat keterlambatan pengiriman. Berdasarkan pengolahan data, pada future state VSM diproyeksikan process cycle efficiency akan meningkat dari 4,1\% menjadi 5,1\%.
\end{abstract}

Kata kunci: waste, value stream mapping, pull, reorder point, continuous review, process cycle efficiency 


\section{PENDAHULUAN}

PT XYZ merupakan suatu perusahaan manufaktur yang bergerak dalam bidang industri rokok. PT XYZ memproduksi rokok dengan berbagai merek, dengan merek $\mathrm{X}$ sebagai produk dengan penjualan terbesar. Saat ini, aktivitas pengiriman material dari warehouse ke lantai produksi belum direncanakan secara sistematis. Maka, perlu disusun rencana perbaikan terhadap pengiriman tersebut. Pengiriman dilakukan oleh seorang OS (Operating Support) berdasarkan perkiraan, sehingga cenderung terjadi penumpukan di lantai produksi. Berikut ini karakteristik yang diamati dalam aktivitas pengiriman material ke lantai produksi: pada pengiriman pertama, OS melakukan loading material di warehouse ke pallet dengan komposisi acak. OS mengirim pallet ke lantai produksi, kemudian mencatat status tiap material pada masing-masing lini dan memperkirakan jumlah material yang diperlukan. OS kembali ke warehouse, kemudian melakukan loading material berdasarkan perkiraan yang telah dilakukan. Berikutnya, OS melakukan loading material di warehouse ke pallet berdasarkan proses yang dituju, contohnya melakukan pengiriman material untuk proses packer. Dalam sekali pengiriman, pallet yang dibawa memuat material yang ditujukan untuk beberapa link-up sekaligus.

Aktivitas pengiriman Direct Input Material (DIM) dari warehouse ke lantai produksi dimulai dengan menerima picklist, memuat jenis material yang digunakan; kemudian loading material ke pallet berdasarkan perkiraan, selanjutnya transportasi material ke semua link-up, tahap selanjutnya unloading material ke trolley, terakhir memperkirakan kebutuhan material untuk pengiriman selanjutnya. Di sisi lain, PT XYZ sedang merencanakan implementasi sistem traceability (telusurjejak) dan pull secara elektronik untuk pengiriman material ke lantai produksi. Berikut karakteristik pengiriman material yang diperlukan dalam implementasi sistem tersebut: pallet atau trolley yang dikirim ditujukan hanya untuk satu mesin, contohnya mesin cigarette packer pada link-up 1.1. Berikutnya, komposisi jenis dan jumlah material pada pallet yang dikirim telah ditetapkan pada sistem (order quantity tetap).

Sebelum menyusun rencana perbaikan, perlu dilakukan pemetaan aliran material as-is (saat ini) PT XYZ dengan tool value stream mapping (VSM). Pemetaan ini bermanfaat untuk menentukan hal-hal yang menjadi prioritas untuk diperbaiki. Penggunaan VSM sebagai metoda perbaikan yang diajukan ini tmengacu pada konsep lean and green (Chen and Frank, 2010) serta studi kasus di pengoperasian truk (Prabhu, et.al, 2008). Analisis aliran material internal dilakukan di sepanjang value stream brand X PT XYZ. Pengamatan aktivitas pengiriman material dilakukan dengan observasi langsung. Pengamatan stock dan konsumsi untuk memetakan average inventory level dilakukan selama 5 shift pada tanggal 24 dan 25 Mei 2011. Simulasi pengiriman material dilakukan sesuai perhitungan kebutuhan berdasarkan uptime tanggal 1-10 Mei 2011. Pengiriman material yang menjadi prioritas perbaikan adalah material-material utama berdasarkan nilai dan tingkat konsumsinya.

Tujuan penelitian ini adalah untuk menganalisis process cycle efficiency (PCE) dalam aktivitas aliran material internal dengan VSM current state, menyusun rencana perbaikan dalam aktivitas pengiriman material dengan mempertimbangkan karakteristik sistem yang akan diimplementasikan, dan memproyeksikan peningkatan PCE pada VSM future state.

\section{METODE}

Langkah-langkah yang dilakukan dalam penelitian ini meliputi: (1) identifikasi masalah; permasalahan pada perusahaan diidentifikasi dengan menelusuri akar penyebab permasalahan melalui pengamatan secara langsung di lapangan, kemudian dilakukan perencanaan metode-metode yang akan 
digunakan untuk menyelesaikan akar permasalahan utama yang ada; (2) studi pustaka; dilakukan dengan mempelajari buku, artikel, jurnal dan referensi-referensi yang terkait secara langsung maupun tidak langsung dengan masalah yang dihadapi. Tujuan studi pustaka adalah memahami konsep dan teori yang dapat digunakan untuk menyelesaikan masalah yang ada; (3) menentukan tujuan dan ruang lingkup; berdasarkan identifikasi masalah dan studi pustaka yang telah dilakukan, ditetapkan tujuan dan ruang lingkup penelitian untuk dapat menyelesaikan permasalahan secara tepat dan efektif; (4) pembuatan peta aliran proses dan informasi; Langkah selanjutnya adalah membuat peta aliran proses dan informasi sebagai gambaran besar semua aktivitas di sepanjang value stream. Peta ini meliputi proses-proses, stock, aliran material, Work-In-Process (WIP) dan/atau Finished Goods dari receiving hingga shipping, serta aliran informasi dari supplier hingga customer.

Peta ini dibuat berdasarkan observasi dan wawancara; (5) mengumpulkan data stock dan konsumsi; data stock dan konsumsi dilakukan dengan pengamatan langung di lapangan. Adapun tahapan pengumpulan data ini yaitu: (a) melakukan penghitungan stock material di tiap mesin (b) Mendata jumlah material yang masuk (c) Menghitung konsumsi material; (d) Menghitung average inventory level (e) Menghitung average inventory level dalam shift. Konsep yang digunakan dalam pertimbangan persediaan ini mengacu pada konsep persediaan Assauri (1999) serta konsep probabilitas dalam persediaan dari Bowersox dan Closs (1996); (6) mengukur waktu transportasi, loading dan unloading; Pengukuran waktu transportasi, loading dan unloading dilakukan dengan metode jam henti (stopwatch). Waktu transportasi yang diukur adalah setiap perpindahan material dan core product antar value stream dari kedatangan material hingga pengiriman material.

Pengukuran dilakukan dengan menggunakan konsep time study melalui pengukuran waktu secara langsung (Barnes, 2009); (7) uji kecukupan dan keseragaman data; tahapan selanjutnya setelah dilakukan pengambilan data adalah melakukan pengujian kecukupan dan keseragaman data. Hal tersebut dilakukan untuk mendapatkan waktu transportasi, loading dan unloading yang akurat serta untuk mendukung kepercayaan serta tingkat ketelitian pada hasil pengukuran yang telah dilakukan; (8) mengisi data pada peta aliran proses (Current State VSM); data transprotasi dan average inventory level yang telah diukur dan dihitung, diisi ke peta aliran material yang telah dibuat.

Dengan langkah ini, maka proses pemetaan kondisi saat ini telah selesai dilakukan. Selanjutnya, dilakukan perhitungan Process Cycle Efficiency (PCE). Nilai PCE adalah efisinesi relative sebuah proses yang mewakili waktu yang digunakan untuk menambak nilai produk dibandingkan dengan total waktu yang dipergunakan produk selama proses per satu siklus part dalam satuan waktu (Gasperz, 2008); (9) menentukan komposisi perhitungan material; menghitung kebutuhan material per shift sesuai target uptime, dan menentukan komposisi pallet dalam pengiriman untuk masing - masing mesin. Langkah ini dilakukan sebagai usulan perbaikan pengiriman material ke lantai produksi; (10) menentukan lead time pengiriman material ke lantai produksi; perhitungan lead time dengan metode yang diusulkan, dilakukan dengan menghitung waktu loading dan transportasi untuk masing-masing pallet; (11) menghitung safety stock dan reorder point; menghitung safety stock dengan metode perbedaan pemakaian maksimum dan rata-rata untuk masing-masing material, serta menghitung reorder point untuk metode Q.

Hal ini dilakukan sesuai dengan pendekatan pull yang akan diimplementasikan (Assauri, 1999, Heizer and Render, 2007); (12) menghitung average inventory level dengan metode yang diusulkan; setelah dilakukan perencanaan, maka dilakukan perhitungan average inventory level dengan metode pengiriman material yang diusulkan; (13) membuat future state VSM; setelah penghitungan average inventory level, dilakukan pembuatan future state VSM dan perhitungan PCE, sehingga dapat dibandingkan dengan rasio sebelum implementasi; (14) kesimpulan dan saran; dari hasil perbaikan yang telah dilakukan kemudian dilakukan evaluasi selanjutnya ditarik kesimpulan dari hasil tersebut serta memberikan usulan-usulan untuk aktivitas pengiriman material dari warehouse ke lantai produksi. 


\section{HASIL DAN PEMBAHASAN}

Sebelum melakukan analisis aliran material internal dengan Value Stream Mapping (VSM), kita harus memahami terlebih dahulu tahapan-tahapan yang dilalui material dari supplier hingga sampai ke customer secara umum. Pemahaman ini diperlukan untuk menciptakan lean manufacturing di perusahaan (Mekong Capital, 2004) Tahapan-tahapan yang dilalui material secara umum digambarkan dalam diagram SIPOC berikut ini (Gambar 1):

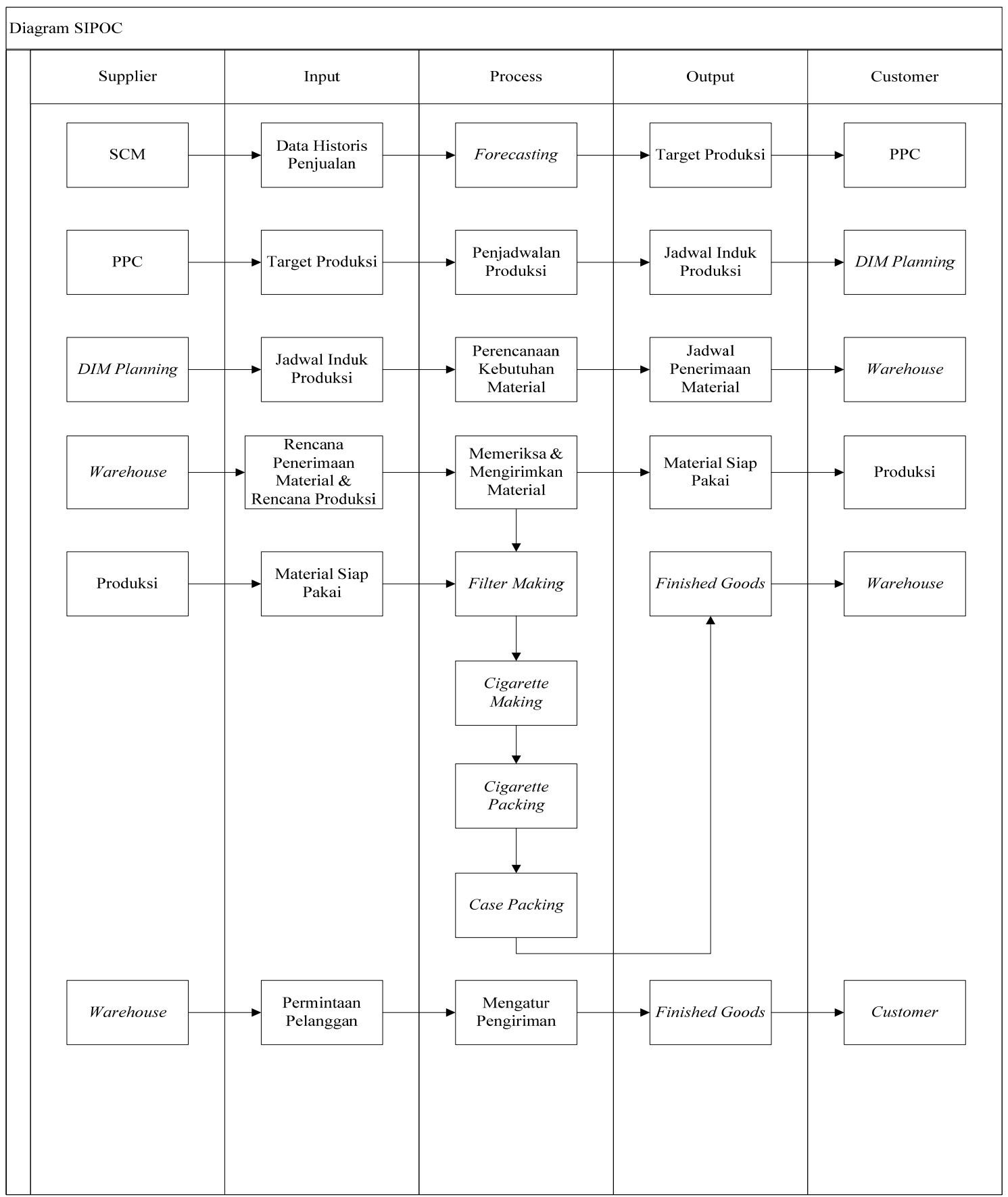

Gambar 1. Diagram SIPOC PT XYZ. 
Current State VSM dibuat dengan menentukan terlebih dahulu produk yang ditelusuri, berdasarkan kesamaan proses produksi. Karena seragamnya proses yang dilalui masing-masing brand pada PT XYZ, produk yang dijadikan sebagai model line untuk pemetaan dan perbaikan adalah brand dengan tingkat penjualan tertinggi, yaitu brand X. Observasi dilakukan mulai dari aktivitas loading material hingga aktivitas unloading produk jadi ke truk. Pengumpulan data dilakukan dengan observasi lapangan untuk melengkapi data transportasi material, inventory level, cycle time, loadingunloading material, serta data-data yang diperlukan dalam process box. Tujuan dari pemetaan adalah untuk mengidentifikasi seluruh jenis pemborosan sepanjang value stream dan untuk mengambil langkah dalam upaya mengeliminasi pemborosan (Rother and Shook, 2003). Hasil dair VSM dapat dijadikan titik balik optimal bagi perusahaan yang ingin menjadi lean.

\section{Average Inventory Level}

Pendataan average inventory level dilakukan dengan memetakan persediaan Direct Input Material (DIM) di lantai produksi. Persediaan yang dicatat berdasarkan pengamatan kemudian dikonversikan ke dalam average inventory level dalam shift, dalam artian tingkat persediaan tersebut cukup untuk memenuhi kebutuhan berapa shift. DIM yang digunakan dalam proses produksi dapat diklasifikasikan menjadi dua, yaitu fast moving dan slow moving. Klasifikasi tersebut dijelaskan dalam Tabel 1 berikut ini.

Tabel 1

Klasifikasi Material (Sumber: pengumpulan data, 2011)

\begin{tabular}{lll}
\hline \multicolumn{1}{c}{ Proses } & \multicolumn{1}{c}{ Material } & \multicolumn{1}{c}{ Klasifikasi } \\
\hline Cigarette Making & Cigarette Paper & Fast Moving \\
\cline { 2 - 3 } & Tipping Paper & Fast Moving \\
\hline Cigarette Packing & Alufoil & Fast Moving \\
\cline { 2 - 3 } & Inner Frame & Fast Moving \\
\cline { 2 - 3 } & Film Pack & Fast Moving \\
\cline { 2 - 3 } & Film Slof & Fast Moving \\
\cline { 2 - 3 } & Blank & Fast Moving \\
\cline { 2 - 3 } & Tear Tape Pack & Slow Moving \\
\cline { 2 - 3 } & Tear Tape Slof & Slow Moving \\
\cline { 2 - 3 } & Blank Label & Slow Moving \\
\cline { 2 - 3 } & Ribbon & Slow Moving \\
\hline Case Packing & Shipping Case & Fast Moving \\
\cline { 2 - 3 } & Case Sealing Tape & Slow Moving \\
\hline
\end{tabular}

Material slow moving adalah material dengan tingkat konsumsi di bawah 1 buah/shift, dan rendah nilainya sehingga tidak menjadi prioritas dalam penelitian ini

Kolom rank menampilkan urutan peringkat average inventory level (Tabel 2) dalam shift, mulai dari yang tertinggi. Berdasarkan harga dan tingkat konsumsinya, material yang diklasifikasikan sebagai material utama oleh $\mathrm{PT}$ XYZ adalah plug wrap dan acetate tow (filter making); cigarette paper dan tipping paper (proses cigarette making); alufoil, inner frame, film pack, film slof, dan blank (proses cigarette packing); dan shipping case (proses case packing). Maka, data yang akan digunakan dalam perhitungan process lead time adalah material dengan shift of supply tertinggi di antara material-material tersebut untuk tiap-tiap prosesnya. 
Tabel 2

Rekapitulasi Hasil Perhitungan Average Inventory Level (dalam shift)

\begin{tabular}{|c|c|c|c|c|c|}
\hline Material & \multicolumn{3}{|c|}{ Link-Up } & $\begin{array}{c}\text { Average Inventory } \\
\text { Level }\end{array}$ & Rank \\
\hline Plug Wrap & \multicolumn{3}{|c|}{ KDF 3} & 0,627 & 12 \\
\hline Acetate Tow & \multicolumn{3}{|c|}{ KDF 3} & 0,461 & 15 \\
\hline Filter & \multicolumn{3}{|c|}{ Staging Filter } & 0,627 & - \\
\hline \multirow[t]{2}{*}{ Cigarette } & \multicolumn{3}{|c|}{ Staging Maker } & 0,746 & - \\
\hline & 1.1 & 3.3 & 4.4 & & \\
\hline Cigarette Paper & 0,278 & 0,827 & 0,467 & 0,606 & 13 \\
\hline Tipping Paper & 0,506 & 0,784 & 1,003 & 0,913 & 11 \\
\hline Alufoil & 0,497 & 1,196 & 0,728 & 0,933 & 10 \\
\hline Inner Frame & 1,125 & 1,815 & 0,579 & 1,346 & 7 \\
\hline Blank & 0,810 & 1,286 & 0,984 & 1,203 & 8 \\
\hline Film Pack & 1,014 & 1,717 & 1,068 & 1,475 & 6 \\
\hline TT Pack & 2,083 & 5,000 & 2,083 & 3,667 & 5 \\
\hline Film Slof & 0,909 & 1,296 & 0,583 & 1,100 & 9 \\
\hline TT Slof & 5,000 & 2,500 & 3,000 & 3,750 & 4 \\
\hline Blank Label & 2,778 & 3,500 & 3,452 & 3,889 & 3 \\
\hline Ribbon & 7,381 & 4,792 & 7,222 & 8,059 & 2 \\
\hline Case Sealing Tape & 0 & 2,500 & 15,000 & 10,500 & 1 \\
\hline Shipping Case & 0,378 & 0,693 & 0,411 & 0,574 & 14 \\
\hline
\end{tabular}

\section{Transportasi}

\section{Uji Keseragaman Data dan Kecukupan Data}

Uji ini dilakukan pada data transportasi, loading dan unloading yang telah dikumpulkan. Berikut adalah rekapitulasi hasil perhitungan uji keseragaman data pada data tiap-tiap aktivitas (Tabel 3):

Tabel 3

Rekapitulasi Uji Keseragaman Data Waktu Transportasi

\begin{tabular}{clc}
\hline No. & \multicolumn{1}{c}{ Aktivitas } & Hasil \\
\hline 1 & Unload material Ke WH & Seragam \\
\hline 2 & Transportasi dari WH ke buffer material & Seragam \\
\hline 3 & Transportasi dari Filter Maker ke buffer Filter & Seragam \\
\hline 4 & Transportasi dari buffer filter ke Filter Shooter & Seragam \\
\hline 5 & Transportasi dari Cigarette Maker ke Cigarette Packer & Seragam \\
\hline 6 & Transportasi dari Cigarette Packer ke Case Packer & Seragam \\
\hline 7 & Transportasi dari Case Packer ke conveyor & Seragam \\
\hline 8 & Palletizing & Seragam \\
\hline 9 & Transportasi dari Palletizing ke finished goods WH (FG WH) & Seragam \\
\hline
\end{tabular}




\begin{tabular}{cll}
\hline 10 & Transportasi dari FG WH ke truk & Seragam \\
\hline 11 & Transportasi dari buffer material ke KDF 3 & Seragam \\
\hline 12 & Transportasi dari buffer material ke Cigarette Maker & Seragam \\
\hline 13 & Transportasi dari buffer material ke Case Packer & Seragam \\
\hline 14 & Transportasi dari buffer material ke Case Packer & Seragam \\
\hline
\end{tabular}

Sebelum data diolah lebih lanjut, diperlukan uji kecukupan data. Pengujian ini menggunakan tingkat ketelitian sebesar 5\% dan tingkat keyakinan sebesar $95 \%$. Berikut adalah rekapitulasi uji kecukupan data waktu transportasi (Tabel 4).

Tabel 4

Rekapitulasi Uji Kecukupan Data Waktu Transportasi

\begin{tabular}{cll}
\hline No. & \multicolumn{1}{c}{ Aktivitas } & \multicolumn{1}{c}{ Hasil } \\
\hline 1 & Unload Material Ke WH & Data cukup \\
\hline 2 & Transportasi dari WH ke Buffer & Data cukup \\
\hline 3 & Transportasi dari Filter Maker ke buffer Filter & Data cukup \\
\hline 4 & Transportasi dari buffer Filter ke Filter Shooter & Data cukup \\
\hline 5 & Transportasi dari Cigarette Maker ke Cigarette Packer & Data cukup \\
\hline 6 & Transportasi dari Cigarette Packer ke Case Packer & Data cukup \\
\hline 7 & Transportasi dari Case Packer ke conveyor & Data cukup \\
\hline 8 & Palletizing & Data cukup \\
\hline 9 & Transportasi dari Palletizing ke WH (Finish Good) & Data cukup \\
\hline 10 & transportasi dari WH ke truck (Finish good) & Data cukup \\
\hline 11 & Transportasi dari buffer material ke KDF 3 & Data cukup \\
\hline 12 & Transportasi dari buffer material ke Cigarette Maker & Data cukup \\
\hline 13 & Transportasi dari buffer material ke Case Packer & Data cukup \\
\hline 14 & Transportasi dari buffer material ke Case Packer & Data cukup \\
\hline
\end{tabular}

Berdasarkan uji kecukupan data yang dilakukan, semua data menunjukkan bahwa $\mathrm{N}<\mathrm{N}$, sehingga data dapat dikategorikan cukup.

\section{Process Box} uptime.

Untuk process box, data yang dikumpulkan adalah data jumlah operator, cycle time dan

\section{Jumlah Operator}

Jumlah operator pada setiap proses sepanjang value stream sebagai berikut:

Filter Making

Cigarette Making = 1 orang/link-up

Cigarette Packing = 1 orang/link-up

Case Packing

Palettizing
$=-$

$=1$ orang 


\section{Cycle Time (CT)}

Data CT untuk produksi satu juta stick adalah sebagai berikut (Tabel 5):

Tabel 5

Cycle Time untuk 1 Juta Stick (dalam Menit)

\begin{tabular}{lrrcc}
\multicolumn{1}{c}{ Proses } & \multicolumn{1}{c}{$\mathbf{1 . 1}$} & \multicolumn{1}{c}{$\mathbf{3 . 3}$} & $\mathbf{4 . 4}$ & Cycle Time Brand X \\
\hline CigaretteMaker & 100,00 & 100,00 & 142,86 & 37,04 \\
Cigarette Packer & 100,00 & 100,00 & 142,86 & 37,04 \\
Case Packer & 0,97105 & 0,97985 & 0,6819 & 37,98 \\
Filter & \multicolumn{2}{c}{$\mathrm{KDF}-3$} & & 42 \\
\hline
\end{tabular}

\section{Uptime}

$\begin{array}{ll}\text { Filter Making } & : 75 \% \\ \text { Cigarette Making } & : 66,06 \% \\ \text { Cigarette Packing } & : 65,33 \% \\ \text { Case Packing } & : 65,33 \%\end{array}$

Berikut adalah data value added and non value added (Tabel 6):

Tabel 6

Data Value Added and Non Value Added

\begin{tabular}{|c|c|c|}
\hline Value Added & \multicolumn{2}{|c|}{ Waktu } \\
\hline CT Filter Maker & 42 & menit \\
\hline CT Cigarette Maker & 37,04 & menit \\
\hline CT Cigarette Packer & 37,04 & menit \\
\hline CT Case Packer & 37,98 & menit \\
\hline Total & 154 & menit \\
\hline Non Value Added ( Necessary) & \multicolumn{2}{|c|}{ Waktu } \\
\hline Unloading Material ke WH & 1,84 & menit \\
\hline Transportasi dari WH ke buffer & 0,75 & menit \\
\hline Transportasi dari Filter Maker ke Staging Filter & 4,78 & menit \\
\hline Transportasi dari Staging Filter ke Shooter & 4,98 & menit \\
\hline Transportasi dari Maker Ke Packer & 21,43 & menit \\
\hline Transportasi dari Packer ke Case Packer & 1342,42 & menit \\
\hline Transportasi dari Case Packer Ke conveyor & 55,37 & menit \\
\hline Palletizing & 10,92 & menit \\
\hline Transportasi dari Palletizing ke warehouse ( FG ) & 4,83 & menit \\
\hline Transportasi dari warehouse ( FG ) ke truk & 6,04 & menit \\
\hline Total & 1453,36 & menit \\
\hline Non Value Added ( Not Necessary) & Wakt & \\
\hline
\end{tabular}




\begin{tabular}{|c|c|c|c|}
\hline Inventory level Filter & & 300,96 & menit \\
\hline Inventory level Staging Filter & & 358,08 & menit \\
\hline Inventory level Maker & & 438,24 & menit \\
\hline Inventory level staging maker & & 36,00 & menit \\
\hline Inventory level packer & & 708,00 & menit \\
\hline Inventory level Packer & & 275,52 & menit \\
\hline & Total & 2116,8 & meni \\
\hline
\end{tabular}

\section{Analisis Value Added dan Non Value Added}

Aktivitas value added yang teridentifikasi adalah data CT filter maker, CT cigarette maker, CT cigarette packer dan data CT case packer. Hasilnya sebesar 154,06 menit.

Sedangkan untuk non value added, waste yang teridentifikasi adalah unloading material dari truk ke warehouse (WH); transportasi dari WH ke buffer; inventory level material filter maker; transportasi dari filter maker ke buffer filter; inventory level pada buffer filter rods; transportasi dari buffer filter ke filter shooter; inventory level material cigarette maker; inventory level cigarette; Transportasi dari cigarette maker ke cigarette packer; inventory level material cigarette packer; transportasi dari cigarette packer ke case packer; inventory level material case packer; transportasi dari case packer ke conveyor; aktivitas palletizing; transportasi dari palletizing ke finished goods WH; dan transportasi dari finished goods WH ke truk.

Nilai value added ratio yang didapatkan dari hasil current state VSM sebesar 4,1\%. Untuk meningkatkan nilai ini, dilakukan rencana perbaikan guna menurunkan waktu dari kegiatan non value added. Selain itu, dilakukan identifikasi waste berdasarkan pengamatan proses dari awal hingga akhir. Pengkategorian waste yang dijadikan acuan adalah konsep waste yang diajukan oleh Toyota (Liker and Meier, 2006).

\section{Identifikasi Waste} (Gambar 2).

Berikut identifikasi waste yang terdapat dalam setiap aktivitas yang dilalui material brand $\mathrm{X}$

Inventory Level

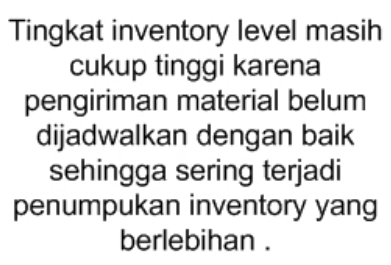

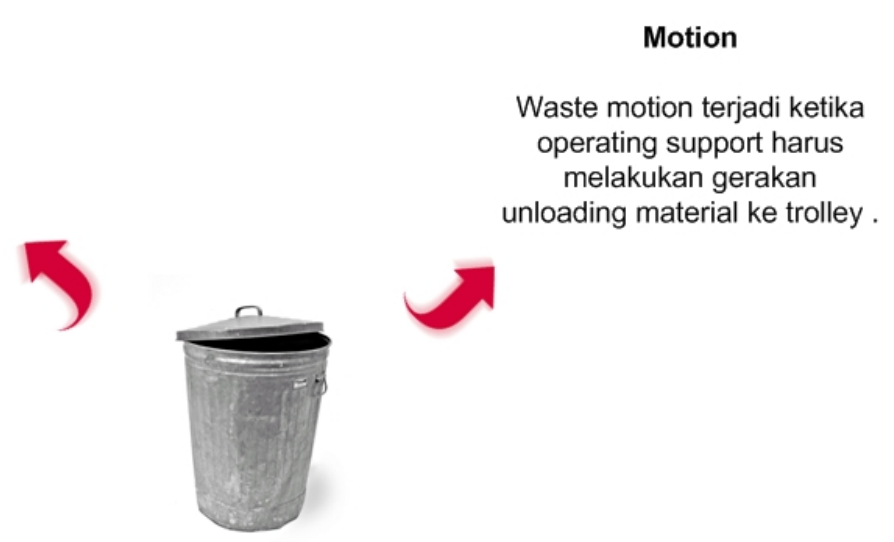

Gambar 2. Identifikasi waste. 
Setelah dilakukan pengamatan, dapat diidentifikasi waste yang terdapat dalam setiap aktivitas. Waste yang teridentifikasi adalah excess inventory level waste dan motion waste. Excess inventory level waste menunjukkan tingkat persediaan yang berlebihan di lantai produksi. Hal ini dikarenakan oleh sistem pengiriman material oleh operating support $(\mathrm{O} / \mathrm{S})$ yang masih dilakukan dengan pendekatan push. Oleh karena itu, perlu dilakukan perencanaan pengiriman material yang lebih baik dengan pendekatan pull. Motion waste terjadi ketika OS melakukan aktivitas pengiriman material ke lantai produksi. Aktivitas yang dilakukan OS adalah loading material, transportasi ke lantai produksi, dan unloading material ke trolley. Operator mesin akan mengambil material dari trolley dan memasukkan material tersebut kedalam mesin. Yang menjadi motion waste dalam rangkaian aktivitas tersebut adalah gerakan unloading material yang dilakukan. Gerakan ini diidentifikasikan sebagai waste, karena sebenarnya ketika gerakan itu dilakukan selain dari sisi waktu akan menjadi lebih lama juga akan mengakibatkan terjadinya double handling antara OS dengan operator mesin.

Pada current state map, diperoleh hasil bahwa non-value added inventory sebesar 2116,8 menit. Berdasarkan hasil perhitungan tersebut, dapat dianalisis bahwa aktivitas non-value added yang ada saat ini sebagian besar dipengaruhi persediaan material yang menumpuk di lantai produksi. Maka, akan disusun rencana perbaikan terhadap aktivitas pengiriman material dari warehouse dengan pendekatan konsep pull. Sesuai dengan karakteristik sistem traceability dan pull secara elektronik yang akan diimplementasikan, maka akan ditentukan komposisi material pada setiap pengiriman Pallet. Untuk pemesanan material oleh operator mesin ke O/S, perlu dilakukan penghitungan reorder point. Sedangkan untuk mengatasi waste motion, akan dilakukan penggantian trolley dengan pallet. Rencana ini bertujuan mengeliminasi gerakan unloading material yang dilakukan, sehingga O/S hanya perlu melakukan kegiatan loading material dan transportasi ke lantai produksi. Setelah dilakukan pemetaan terhadap current state dan future state VSM, dapat dibandingkan hasil yang diproyeksikan dari rencana perbaikan yang dilakukan. Dari current state VSM, diperoleh hasil process lead time sebesar 3724,22 menit dan process cycle efficiency sebesar $4.1 \%$, setelah dilakukan rencana perbaikan hasil dari process lead time berkurang menjadi 3007,10 dan process cycle efficiency meningkat menjadi $5.1 \%$.

\section{Lead Time Pengiriman Material ke Lantai Produksi}

Data lead time berikut adalah waktu yang diperlukan oleh Operating Support (OS) untuk loading material ke pallet dan transportasi dari DIM buffer ke lantai produksi (Tabel 7).

Tabel 7

Lead time loading material ke pallet

\begin{tabular}{cr}
\hline No Pallet & Lead Time (dlm detik) \\
\hline 1 & 176,938 \\
2 & 477,648 \\
3 & 80,83 \\
4 & 76,480 \\
5 & 174,336 \\
6 & 477,264 \\
7 & 80,299 \\
8 & 60,992 \\
9 & 140,153 \\
10 & 362,202 \\
11 & 74,599 \\
12 & 67,908 \\
13 & 164,510 \\
14 & 475,492 \\
15 & 78,527 \\
16 & 68,460
\end{tabular}




\begin{tabular}{rr}
17 & 106,140 \\
18 & 140,196 \\
19 & 396,208 \\
20 & 78,527 \\
\hline
\end{tabular}

\section{Safety Stock dan Reorder Point (ROP)}

Perhitungan safety stock dilakukan dengan metode perbedaan antara konsumsi maksimum (konsumsi material untuk uptime 100\%), dengan konsumsi rata-rata (konsumsi material untuk uptime 70\%) berdasarkan BOM. Berdasarkan hasil perhitungan, didapat bahwa reorder point untuk material berbentuk roll tidak berupa bilangan bulat. Maka, nilai ini harus dibulatkan dengan mempertimbangkan faktor best practice. Sedangkan reorder point material blank, yang berupa bundle lembaran kertas tipis (500 piece per bundle) harus disesuaikan ke kelipatan 500 di atasnya. Demikian pula shipping case, yang berupa bundle 10 pc harus disesuaikan ke kelipatan 10 di atasnya. Hasil perhitungan reorder point cigarette paper link-up 1.1 adalah sebesar 0,32 unit (Tabel 8).

\section{Simulasi Pengiriman Material}

Berdasarkan perhitungan reorder point serta komposisi material pada pallet yang akan diusulkan, dilakukan simulasi order dan pengiriman material (Tabel 9) berdasarkan uptime mesin selama 30 shift pada tanggal 1-10 Mei. Untuk simulasi ini, kita perlu mempertimbangkan pula pengiriman material untuk produksi brand lain sesuai tanggung jawab OS. Hal ini dilakukan untuk mengetahui apakah OS dapat memenuhi semua order tepat waktu. Berdasarkan simulasi yang dilakukan, diperoleh data keterlambatan maksimum yang terjadi dalam memenuhi suatu pesanan pallet yaitu selama 8,29 menit. Oleh karena itu, perlu dilakukan penyesuaian terhadap safety stock dan reorder point yang telah dihitung sebelumnya untuk mengantisipasi keterlambatan. Penyesuaian ini diperlukan untuk mencegah terjadinya stock-out akibat keterlambatan pengiriman material.

Tabel 8

Safety Stock di Link-Up 1.1

\begin{tabular}{lccccccc}
\hline Material & UoM & Rata - rata & Maks & $\begin{array}{c}\text { Lead } \\
\text { time } \\
\text { (shift) }\end{array}$ & $\begin{array}{c}\text { Safety } \\
\text { Stock }\end{array}$ & $\begin{array}{c}\text { Reorder } \\
\text { Point }\end{array}$ & $\begin{array}{c}\text { Reorder } \\
\text { Point } \\
\text { (visual) }\end{array}$ \\
\hline Cigarette Paper & roll & 36,20 & 51,71 & 0,0061 & 0,10 & 0,32 & 1 \\
Tipping Paper & roll & 13,10 & 18,72 & 0,0061 & 0,03 & 0,11 & 1 \\
Alufoil & roll & 24,83 & 35,47 & 0,0166 & 0,18 & 0,59 & 1 \\
Inner Frame & roll & 8,20 & 11,71 & 0,0166 & 0,06 & 0,19 & 1 \\
Film Pack & roll & 9,46 & 13,51 & 0,0166 & 0,07 & 0,22 & 1 \\
Film Slof & roll & 2,44 & 3,48 & 0,0166 & 0,02 & 0,06 & 1 \\
Blank & ribu pc & 169,18 & 241,68 & 0,0028 & 0,20 & 0,68 & 1 \\
Shipping Case & $p c$ & 337,01 & 481,44 & 0,0027 & 0,38 & 1,28 & 2 \\
\hline
\end{tabular}

Tabel 9

Hasil Simulasi Pengiriman Material

\begin{tabular}{rrrrrrr}
$\begin{array}{l}\text { Waktu } \\
\text { Order }\end{array}$ & Pallet & $\begin{array}{l}\text { Lead } \\
\text { time }\end{array}$ & Terkirim & Selesai & Status & Keterlambatan \\
\hline 0.12 & 11 & 1,24 & 1,36 & 2,41 & & \\
8.30 & 20 & 1,14 & 9,44 & 10,49 & Terlayani & 0,00
\end{tabular}




\begin{tabular}{rrrrrll}
59.65 & 17 & 2,34 & 61,98 & 63,03 & Terlayani & 0,00 \\
112.49 & 12 & 1,13 & 113,62 & 114,67 & Terlayani & 0,00 \\
120.48 & 15 & 1,31 & 121,79 & 122,84 & Terlayani & 0,00 \\
133.54 & 16 & 1,14 & 134,68 & 135,73 & Terlayani & 0,00 \\
139.21 & 18 & 6,60 & 145,81 & 146,86 & Terlayani & 0,00 \\
175.94 & 4 & 1,27 & 177,21 & 178,26 & Terlayani & 0,00 \\
211.10 & 14 & 7,26 & 218,37 & 219,42 & Terlayani & 0,00 \\
220.51 & 10 & 6,04 & 226,55 & 227,60 & Terlayani & 0,00 \\
253.86 & 9 & 2,34 & 256,19 & 257,24 & Terlayani & 0,00 \\
339.98 & 20 & 1,14 & 341,12 & 342,17 & Terlayani & 0,00 \\
344.22 & 16 & 1,14 & 345,37 & 346,42 & Terlayani & 0,00 \\
346.72 & 3 & 1,34 & 348,06 & 349,11 & Terlayani & 0,00 \\
357.62 & 13 & 2,74 & 360,37 & 361,42 & Terlayani & 0,00 \\
357.91 & 12 & 1,13 & 362,55 & 363,60 & Terlambat & 3,51 \\
358.00 & 4 & 1,27 & 364,87 & 365,92 & Terlambat & 5,60 \\
425.03 & 2 & 7,96 & 432,99 & 434,04 & Terlayani & 0,00 \\
425.75 & 5 & 2,91 & 436,95 & 438,00 & Terlambat & 8,29 \\
430.67 & 19 & 1,31 & 439,30 & 440,35 & Terlambat & 7,33 \\
440.27 & 1 & 2,95 & 443,30 & 444,35 & Terlambat & 0,09 \\
\hline
\end{tabular}

\section{Analisis Future State VSM}

Pada pemetaan future state VSM, digambarkan bahwa adanya penurunan nilai inventory level pada proses cigarette maker dari 0,913 shift menjadi 0,542 shift, cigarette packer dari 1,475 shift menjadi 0,691 shift, dan case packer dari 0,574 shift menjadi 0,235 shift. Penurunan nilai inventory level ini mengakibatkan nilai non value added pun menjadi lebih kecil, sehingga akan menaikkan nilai process cycle efficiency.

\section{Analisis Perbandingan Current State dengan Future State}

Setelah dilakukan pemetaan terhadap current state dan future state VSM, kita dapat membandingkan hasil yang diproyeksikan dari rencana perbaikan yang dilakukan. Dari current state VSM, diperoleh hasil process lead time sebesar 3724,22 menit dan process cycle efficiency sebesar 4.1 $\%$, setelah dilakukan rencana perbaikan hasil dari process lead time berkurang menjadi 3007,10 dan process cycle efficiency meningkat menjadi $5.1 \%$.

\section{PENUTUP}

Berdasarkan penelitian, dapat diidentifikasi aktivitas value added dan non value added di sepanjang value stream brand $\mathrm{X}$. Waste yang teridentifikasi adalah excessive inventory dan motion. Nilai PCE yang diperoleh pada VSM current state sebesar 4,1\%. Untuk itu, disusun rencana perbaikan dalam pengiriman material dengan menggunakan pendekatan pull. Perbaikan yang diproyeksikan pada VSM future state sebesar 5,1 \%. Perbaikan dilakukan melalui penyesuaian safety stock dan penentuan reorder point untuk setiap material yang diperlukan pada brand $\mathrm{X}$ untuk menghindari keterlambatan pengiriman. Selain itu, untuk mengurangi penumpukan material di lantai produksi, dilakukan pendekatan pull dalam pengiriman material dari buffer area ke lantai produksi. 


\section{DAFTAR PUSTAKA}

Assauri, S. (1999). Manajemen Produksi dan Operasi. Fakultas Ekonomi Universitas Indonesia, Jakarta.

Barnes, R. M. (2009). Motion and Time Study and Measurement of Work. India: Wiley.

Bowersox, Donald J., Closs, David J. (1996). Logistical Management: The Integrated Supply Chain Process (1st Edition ed.). New York: McGraw Hill.

Chen, Kuriger, Glenn W., \& Frank, F. (2010). Lean and Green: A Current State View. IIE Journal.

Heizer, Jay H., Render, Barry (2007). Operation Management: Student Lecture Guide. New Jersey: Pearson Prentice Hall.

Liker, J. K \& Meier, D. (2006). The Toyota Way Fieldbook. New York: McGraw-Hill.

Mekong Capital. (2004). Introduction to Lean Manufacturing. Diakses dari http://www.google.co.id/url?sa=t\&rct=j\&q=\&esrc=s\&source=web\&cd=1\&ved=0CCQQFjAA\&url=ht tp\%3A\%2F\%2Fwww.lean6sigma.vn\%2FDownload-document\%2F2-Lean-

Manufacturing.html\&ei=QM1_T9GtN8vRrQeT7LD6BQ\&usg=AFQjCNEmioHEXRrzwTeVHi8oYH wxr-NsOA\&sig2=9S6uTiUQUXpg9dlBlG_SMg.

Prabhu, B Vittaldasa, et al. (2008). Value stream mapping of truck operations: a case study. South Asian Journal of Management, 15 (2).

Rother, M dan Shook, J. (2003). Learning to See, Value Stream Mapping to Create Value and Eliminate Muda. Cambridge: The Lean Enterprise Institute. 